DOI: http://dx.doi.org/10.33846/hn20618

http://heanoti.com/index.php/hn

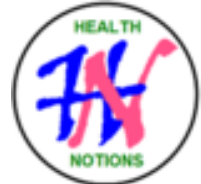

RESEARCH ARTICLE

URL of this article: http://heanoti.com/index.php/hn/article/view/hn20618

\title{
Application of Back Massage to Decrease Pain Lavel in Elderly in Social House of
} Tresna Werdha Bondowoso

\author{
Mahmud Ady Yuwanto ${ }^{1(\mathrm{CA})}$, Yugi Chandra Hari Purnama ${ }^{2}$, Rizki Eko Prasetyo ${ }^{3}$ \\ ${ }^{1(\mathrm{CA})}$ Department of Nursing, STIKes dr. Soebandi Jember, Indonesia; may@stikesdrsoebandi.ac.id \\ (Corresponding Author) \\ ${ }^{2}$ Department of Nursing, STIKes dr. Soebandi Jember, Indonesia; yuggie90@ gmail.com \\ ${ }^{3}$ Department of Nursing, STIKes dr. Soebandi Jember, Indonesia; rizkieko.prasetyo@ gmail.com
}

\begin{abstract}
Back massage is a smooth movement and pressure on the surface of the skin done on the back. Back massage therapy has a variety of benefits for the body and body system where the body will experience improvement and positive effects after back massage. As for some body systems that receive positive effects of back masssage therapy are the nervous system, muscular system, skeletal system, circulatory system, respiratory system, digestive system, reproduction system, lymph nodes, and skin. With a back massage the body will feel the relaxation so that the felt nyari reduced. The purpose of this study was to determine the effect of back massage on the decrease of pain in elderly in Social House Tresna Werdha Bondowoso. The design of this study used the control group pretest-postets design. The sample size was 40 elderly. In this study back massage technique was given 3 times with a duration of 45 minutes. Statistical test using T-test with p-value of 0.00. Back masage therapy provides positive energy for the elderly where this therapy provides a sense of relaxation and comfort for the elderly so that the pain felt by the elderly decreased as a result of the technique that gives a comfortable sensation.
\end{abstract}

Keywords: pain level; back massage; elderly

\section{INTRODUCTION}

Biologically, the elderly experience a decrease in physical endurance continuously and susceptible to disease that can cause death. According to Bustan ${ }^{(1)}$, the physical condition of the elderly has decreased appearance such as on the face, hand, and skin, decreased function in the body such as nervous system, stomach, spleen, and liver, decreased ability of senses like sight, hearing, smell, and taste as well as motor degradation such as strength and speed. These changes lead to a decline in physical and psychological health that will affect the activities of daily life of the soul. ${ }^{(2)}$

Along with the increasing age also the percentage of elderly who suffer health complaints, except for complaints of toothache and colds. The most common type of health complaints experienced by the elderly are other complaints, namely the type of health complaints that are specifically suffered by the elderly such as uric acid, high blood pressure, low blood pressure, rheumatism, diabetes, and various other chronic diseases. Other types of complaints suffered by 20.03 percent of the pre-elderly population, 30.83 percent of young elderly, 39.79 percent of middle-aged, and 46.76 percent old elderly.

Of the various complaints felt by the elderly pain response is the most dominant complaint felt by the elderly. The presence of pain to make the patient is often afraid to move so that interfere with daily activities and can reduce productivity. In addition, with experiencing pain, is enough to make the patient frustrated in life everyday so that it can offend patient fit feeling. Therefore, the main therapy that is directed is to deal with this pain. $^{(3)}$

Back Massage is one of the techniques of giving massage action on the back with a slow stroke ${ }^{(4)}$. Stroke with lotion/balm provides a warm sensation by causing dilatation of local blood vessels. Vasodilation of blood vessels will increase blood circulation in the area so that cell activity is increased and will reduce pain and support the healing process. ${ }^{(5)}$ 
The purpose of this study was analyze the effectiveness back massage to decrease pain level.

\section{METHODS}

The design of this study was the control group pretest-postets. The sampel size to 40 elderly with sampling using purposive sampling technique. In this study back massage technique was given 3 times with a duration of 45 minutes. Instrument of data collection using Visual Analog Scale and then the data was analyzed using t-test.

\section{RESULTS}

Tabel 1. Differences of pain levels before and after intervention

\begin{tabular}{ccccc}
\hline \multirow{2}{*}{ No } & Group & Intervention & Mean & p-value \\
\hline \multirow{2}{*}{1} & \multirow{2}{*}{ Experiment } & Before back massage & 3.45 & 0.000 \\
\cline { 3 - 5 } & & After back massage & 2.45 & 0.000 \\
\hline \multirow{2}{*}{2} & \multirow{2}{*}{ Control } & Before the intervention & 3.50 & 0.000 \\
\cline { 3 - 5 } & & After the intervention & 3.35 & 0.000 \\
\hline
\end{tabular}

Tabel 2. Paired sample t-test results

\begin{tabular}{clcll}
\hline No & Experiment Group & Mean & Standart deviation & p-value \\
\hline 1 & T-test of experiment group & 1.000 & 0.562 & 0.000 \\
\hline 2 & T-test of control group & 0.150 & 0.489 & 0.186 \\
\hline
\end{tabular}

Table 1 shows the mean score of pain level before the back massage therapy in the experimental group was 3.45 whereas the main score of pain level in the control group was 3.50. There was no difference in the level of pain of the respondents before the intervention of the experimental group and the control group was given.

The main score of pain level after back massage in the experimental group was 2.45 , whereas the main score of pain level in the control group after the intervention was 3.35, so it can be concluded that there was a difference of pain level after the intervention was given between the experimental group and the control group. From table 2 it can be concluded that in the experiment group, there was influence of back massage therapy on decrease pain. Based on statistical test showing there was influence with the p-value of 0.000 .

\section{DISCUSSION}

Pain is an unpleasant sensory and emotional experience due to tissue damage or potential tissue damage or a picture of tissue damage ${ }^{(6)}$. Severe pain and sudden attacks are threats that affect humans as open systems to adapt from stressors that threaten and disrupt balance. The hypothalamus responds to painful stimuli from peripheral receptors or the cerebral cortex via the pituitary and adrenal hypothalamic system with the mechanism of the hypophysial adrenal medulla to suppress non-essential functioning for life resulting in the loss of tense and cortexadrenal hypophysical mechanisms to maintain fluid and electrolyte balance and provide energy under conditions emergency to accelerate healing ${ }^{(7)}$.

Complaints of pain can affect happiness, desire, hope, peace of mind, the ability to feel the satisfaction of life and enjoy life. Other disorders may include decreased activity and non-compliance in the treatment and treatment process. This problem requires solving as an effort to assist the patient in adapting to the problem or the pressure he is feeling. When patients complain of pain, then only one they want, that is to reduce pain or pain. It's natural because pain is the worst torment that lowers the will to achieve something in life, it even becomes a frightening and unpleasant experience due to inadequate pain management. Severe pain and sudden attacks if not treated promptly will affect the increase in blood pressure, tachycardia, dilated pupils, diaphoresis and adrenal secretions of the medulla. In certain situations can also occur. Blood pressure drop will result in $\operatorname{shock}^{(6)}$. The action to overcome pain is pain management. Pain management consists of non pharmacological treatment.

The presence of pain to make the patient is often afraid to move so that interfere with daily activities and can reduce productivity. In addition, with experiencing pain, is enough to make the patient frustrated in life everyday so that it can interfere with patient comfort. Therefore, the main therapy that is directed is to deal with this pain ${ }^{(8)}$. Back Massage is one of the techniques to provide massage action on the back with a slow stroke ${ }^{(4)}$. Stroke with lotion / balm provides a warm sensation by causing dilatation of local blood vessels. Vasodilatation of blood vessels will increase blood circulation in the area so that cell activity is increased and will reduce the sense of kit and support the wound healing process. ${ }^{(5)}$ 
Actions to overcome pain were pain management. Pain management consists of non pharmacological treatment and pharmacological treatment. Pharmacological pain management according to Corwin ${ }^{(9)}$ includes the use of analgesics, nonsteroidal anti-inflammatory drugs, and narcotics aimed at reducing pain. One way that is used to reduce rheumatic pain is by way of back massage. The mechanisme of pain reduction can be explained by the gate control theory that the intensity of pain is lowered by blocking the transmission of pain on the gate and Endorphin theory is decreased in pain intensity is influenced by increased levels of endorphins in the body. With the therapy of back massage can stimulate the beta fibers are widely available in the skin and respond to light massage on the skin so that impulse delivered faster.

This stimulation makes the dominant impulse input derived from A beta fibers so that the gate closes and the pain impulse can not be passed on to the cerebral cortex to be interpreted as pain ${ }^{(10)}$. In addition, the descending control system will also react with releasing endorphin which is the body's natural morphine to block transmission of pain and pain perception does not occur ${ }^{(3)}$. So the perceived intensity decreases.

In the implementation of back massage in social institutions tresna werdha bondowoso the elderly get nursing therapy in nonfarmokologis that is given the back massage intervention. Many elderly feel a positive sensation after being given back massage therapy one of them is decreased of joint pain often felt by elderly in social house of tresna werdha bondowoso. Elderly admitted that after being given back massage therapy his body feels more comfortable and the body feels more relaxed, the body more lightly and the body feel more fit.

Back massage therapy provides positive energy for the elderly where this therapy provides a sense of relaxation and comfort for the elderly so that the pain felt by the elderly decreased as a result of the massage technique that provides a comfortable sensation. Decreasing in pain is experienced by elderly people due to increase hormone endorphins in the hormone that regulated the body to feel relaxed and happy senses. Many elderly confussed after being given backage therapy elderly people feel to fit body and the pain is felt slowly reduced.

\section{CONCLUSION}

1. The main score of pain level before the back massage therapy in the experimental group was 3.45 while the mean pain level in the control group was 3.50. There was no difference in the level of pain of the respondents before the intervention of the experimental group and the control group was given

2. The mean of pain level after given back massage in the experimental group was 2.45 , while the average pain level in the control group after the intervention was 3.35, so it can be concluded that there was a difference of pain level after the intervention was given between the experimental group and the group control.

3. There is an effect of back massage therapy on pain reduction. Based on statistical test showed there is influence with result $\mathrm{p}$ value 0.000 . While in the control group there was no effect of giving interevnsion to the decrease of pain. Based on statistical test showing there is influence with result $p$ value 0.186 .

\section{REFERENCES}

1. Bustan. Epidemiology of Non-Communicable Diseases (Epidemiologi Penyakit Tidak Menular). Jakarta: Rineka Cipta; 2007.

2. BPS Indonesia. Elderly Population Statistics (Statistik Penduduk Lanjut Usia). Jakarta: Badan BPS Indonesia; 2014.

3. Potter PA, Perry AG. Fundamentals of nursing. St Louis, Missouri: Elsevier Mosby; 2013.

4. Kenworthy, Snowley, Gilling. Common Foundation Studies in Nursing, Third Edition. USA: Churchill Livingstone; 2002 ..

5. Kusyati E. Laboratory Skills and Procedures (Keterampilan dan Prosedur Laboratorium). Jakarta: EGC; 2006.

6. Smeltzer \& Bare. Medical-Surgical Nursing (Keperawatan Medikal Bedah), Jakarta: EGC; 2002.

7. Long BC. Surgical Medical Care (An Approach to the Nursing Process) (Perawatan Medikal Bedah (Suatu Pendekatan Proses Keperawatan)). Bandung: Yayasan IAPK Padjajaran; 2001.

8. Potter PA, Perry AG. Fundamentals of Nursing (Fundamental Keperawatan). $7^{\text {th }}$ Ed. Book 1 dan 2. Jakarta: EGC; 2009.

9. Corwin EJ. Pocket Book of Pathophysiology (Buku Saku Patofisiologi). Jakarta: EGC; 2007.

10. Guyton \& Hall. Medical Physiology (Fisiologi Kedokteran). Jakarta: EGC; 2007. 